\title{
Banor i samhällsvården - en tvåårsstudie om unga som utretts på SiS-institution
}

\author{
SOFIA ENELL ${ }^{1}$
}

\begin{abstract}
Unga kan placeras på Statens institutionsstyrelses (SiS) institutioner för att utredas tvärprofessionellt. Utredningarna leder fram till förslag på fortsatt vård som socialtjänsten tar ställning till och beslutar om. I artikeln analyseras en sekvens av utredda ungas banor $i$ samhällsvården.
\end{abstract}

\section{Inledning}

Barn och unga placeras utanför sitt hem när deras behov av skydd och stöd inte kan tillgodoses i ursprungsfamiljen. Samhällsvården i Sverige berörde 2012 nästan 29600 unga och merparten (ca 21 300) var mellan 13 och 20 år (Socialstyrelsen, 2013). ${ }^{2}$ Ett övergripande mål med placeringar i samhällsvård är att barn och unga ska få ökad trygghet och

1 Sofia Enell är doktorand vid institutionen för socialt arbete, Linnéuniversitetet.

2 Begreppet samhällsvård kommer att användas i artikeln avseende socialtjänstens placeringar av barn och unga på heltid i en vårdmiljö utanför hemmet (se även Spånberger Weitz, 2011:15). större förutsägbarhet, men forskning visar att vården snarare kan bidra till en ökad komplexitet i deras liv. Som en följd av placeringarna innebär samhällsvården nya sociala arenor som de unga måste förhålla sig till (Egelund \& Jakobsen, 2011). Det kan handla om nya relationer till personal och unga vid en institution eller att hitta sin roll i förhållande till vuxna och barn i ett familjehem. Att integrera nya arenor med befintliga kan innebära flera svårigheter. Arenorna kan innehålla olika normsystem, vilket i sin tur kan leda till lojalitetskonflikter för unga. I Anderssons (2008) longitudinella studie framkommer en annan form av komplexitet. Även om det fanns stora variationer var helhetsintrycket av samhällsvården 
att den var instabil, något som manifesterade sig i att de unga flyttade i såväl planerade som högst oplanerade former. Risken för det senare, så kallat sammanbrott, gäller särskilt unga med beteendeproblem (Oosterman et.al., 2006; Sallnäs et.al., 2004; Ward, 2009).

Den ökade komplexiteten i tillvaron och de många arenorna som ska bemästras är i hög grad aktuell för unga som placeras på institution för att utredas. Utöver institutionsarenan med personal och andra unga tillkommer utredningsprocesser där de som utreder föreslår åtgärder till socialtjänsten. Utredningsplaceringen i sig innebär att unga måste flytta både till och från institutionen. Flera studier har visat att placeringar kräver avancerade färdigheter hos unga avseende anpassning, kommunikation och att tyda sociala koder (Egelund \& Jakobsen, 2011; Espersen, 2010; Levin, 1998; Stokholm, 2006). I en utredningssituation ställs det ytterligare krav på de unga, till exempel att försäkra sig inflytande i en utredning.

Statens institutionsstyrelse ansvarar för särskilda ungdomshem (SiSinstitutioner) där unga kan placeras för att utredas. SiS-institutioner har historiskt haft ett dubbelt uppdrag i att erbjuda både samhällsskydd och barnaskydd, något som också gäller idag (Levin, 1998; Lundström \& Sallnäs, 2012). Unga kan placeras på låsta avdelningar och det finns möjligheter att inom institutionen ytterligare begränsa de ungas rörelsefrihet och kontakter. SiS ungdomsgrupp är heterogen, men brukar beskrivas som ungdomsvårdens mest problemtyngda
(Shannon, 2011; Vogel, 2012). Flertalet av dem har varit placerade tidigare, de återplaceras i hög utsträckning och rapporterar själva om omfattande problematik kopplat till både omgivning och egna problem. SiS-utredningar berör årligen cirka 325 unga och varje utredning genomförs under åtta veckor. Utredningarna innehåller, enligt myndighetens föreskrifter, utlåtande från psykolog, pedagog, familj- och nätverksutredare, avdelningspersonal och läkare. ${ }^{3}$ I utredningarna lämnas förslag på interventioner för socialtjänsten att ta ställning till och besluta om.

Denna artikel handlar om unga som utretts vid SiS-institutioner och deras tid i samhällsvård efter utredning. De unga har följts under två år genom enkäter till yrkesverksamma samt intervjuer med 16 unga och deras socialsekreterare. Med ett fokus på sociala processer utifrån begreppet "banor" (trajectories) (Glaser \& Strauss, 1968; Strauss et.al., 1997) har en period i de ungas liv analyserats. Utredning kan ses som ett centralt instrument för att bedöma vilken vård unga med en problematisk livssituation behöver, men också för att uppnå förutsägbarhet och stabilitet i fortsatta åtgärder i de ungas liv. Här förstås utredning som en del av en bana som formas i interaktion mellan den unge och olika aktörer. Syftet med artikeln är att analysera en sekvens av utredda ungas banor i samhällsvården i relation till SiS-utredningar. Följande frågor behandlas:

3 Ungefär 1100 unga/år placeras på SiS-institutioner. 
1.Utifrån interaktionen mellan de unga och deras socialsekreterare - vilka typer av banor kan urskiljas för de utredda unga?

2.Vilka händelseförlopp framträder i dessa banor avseende stabilitet och instabilitet?

3. Vilka händelseförlopp framträder i hela gruppen av unga avseende stabilitet och instabilitet?

\section{Banorför unga som utreds på SiS-institution}

I tidigare studier om ungas tid i samhällsvård har begrepp som banor eller stigar (Pösö \& Eronen, 2013), karriärbanor (Stein, 1994), vårdkarriärer (Fisher et.al., 1986) och placeringshistoria (Andersson, 2008) använts. Dessa begrepp har haft fokus på olika händelseförlopp i samhällsvården. Här har begreppet "banor" valts med utgångspunkt i Strauss (1968; 1997) begrepp "trajectories". "Trajectory" kan översättas med "bana" som kan sägas starta när den unge får kontakt med socialtjänsten. Med begreppet betonar Strauss handlingsprocessen, en sekventiell ordning av planering, förväntan, samarbete och konsekvenser av handling (Soeffner, 1991 s. 368). Banan formas av involverade aktörer, framförallt av dem som står i centrum för handlingen, men även av mer perifera aktörer. På så sätt finns det ingen central planerare av banan, istället är det den sociala organiseringen och interaktionen som är banan. Strauss $(1968 ; 1997)$ fann i sina studier om banor på sjukhus att de har potential att vara både komplexa och problematiska eftersom de präglas av osäkerhet i problematiken, organisato- riska resurser och de inblandades tidigare erfarenheter. Dessutom formas de av och genom arbete av människor.

Här kommer banor hos en grupp unga att analyseras utifrån hur två centrala aktörer, de unga och deras socialsekreterare, interagerar och formar banan i relation till SiS-utredningen. Till analysen kopplas även händelseförlopp avseende stabilitet och instabilitet i de ungas boende, byte av socialsekreterare och nya externa utredningar. Analysen avser en sekvens av de ungas pågående banor: från SiS-utredningarna och två år framåt.

\section{Utredning och samhällsvård av unga}

Socialtjänstens utredningar av unga har länge kritiserats för brist på saklighet, avsaknad av de ungas perspektiv och svag informationsinhämtning (Sundell et.al., 2007). Munro (1996) beskriver arbetet med en barnavårdsutredning som att lägga ett pussel utan att veta vad pusslet föreställer eller vilka bitar som hör till. Det är därför svårt att avgöra när utredningen är färdig, vilket kompliceras ytterligare av att informationen på pusselbitarna kan vara mångtydig och otillförlitlig. Att ge utredningsuppdrag till externa utförare som SiS kan vara ett sätt för socialtjänsten att få ungas problematik specificerad och de mångtydiga motiven på pusselbitarna klargjorda. Studier om SiS-utredningar finns från 1990-talet och visar låg följsamhet av socialtjänsten till utredningarnas rekommendationer samt fortsatt instabilitet i placeringar (Michanek et.al., 2000; Sandell \& Olsson, 1998; Sarnecki, 1992). 


\section{Instabilitet i samhällsvård}

Ungas tid i samhällsvård varierar stort då vissa placeras tillfälligt och andra mer långvarigt (Andersson, 2008). Hur tiden gestaltar sig påverkas även av instabiliten i placeringarna. Studier som undersökt instabilitet i samhällsvård har i huvudsak studerat oplanerade avbrott (sammanbrott) (Oosterman et.al., 2006; Sallnäs et.al., 2004). Upp till 44 procent av samhällsvårdade unga erfar sammanbrott (Egelund et.al., 2010;Sallnäs et.al., 2004;Skoog et.al., 2012). Sammanbrott är en del av instabilitet i samhällsvård, en annan att unga flyttar planerat mellan olika placeringar och en tredje att unga som flyttar hem från samhällsvård återplaceras senare. Unga i samhällsvård kan ha erfarenheter av instabil tillvaro både före och efter tiden i samhällsvård, vilket kan innebära att uppväxten som helhet utmärks av återkommande flyttningar (Spånberger Weitz, 2011;Ward, 2009).

Christiansen m.fl. (2010) menar att instabilitet för unga i samhällsvård kan förebyggas med grundliga utredningar. Samtidigt visar Egelund m.fl. (2010) i sin studie att begränsade resurser och brist på bärande relationer till vuxna bidrar till att en placering bryter samman. Egelund m.fl. fann också att unga och yrkesverksamma på institution befinner sig $\mathrm{i}$ institutionella parallellvärldar, där unga relaterar mer till normer i ungdomsgruppen än till behandlingsideal.

Flera forskare har funnit att systemet i sig kan motverka stabilitet (Egelund et.al., 2010; Skoog, 2013; Ward, 2009), exempelvis när välfungerande placeringar avbryts av ekonomiska skäl eller när unga placeras i tillfälliga hem (jour-/akut-/ utredningshem) i avvaktan på permanent placering. Upprepade handläggarbyten $i$ socialtjänsten kan också vara en instabilitet - skapad av systemet.

\section{Ungas erfarenheter}

I studier framkommer att unga i samhällsvård ofta uppfattar att de saknar egen kontroll och makt över sina liv, samtidigt som de är utlämnade åt sig själva (Egelund et.al., 2010; Samuel \& Pryce, 2008). De undviker emotionella beroendeförhållanden, gör val som gynnar deras egenkontroll och gör motstånd mot yrkesverksammas problembeskrivningar för att bevara självbilden som mångfacetterade individer (Espersen, 2010; Samuel \& Pryce, 2008; Spånberger Weitz, 2011). Unga kan själva beskriva hur de väljer att agera ut för att åstadkomma förändring i placeringen när de uppfattar det som om de vuxna inte lyssnar (Skoog, 2013).

Etnografiska studier visar att unga på låsta institutioner främst försöker få tiden att gå, vilket tillsammans med resursbrist och osäkerhet över vistelselängd hindrar en positiv utveckling (Bengtsson, 2012; Egelund \& Frydensbjerg, 2011; Levin, 1998). När Berglund (1998) följde utredda unga från SiS-institutioner fann han att deras vändpunkter kom genom relationer i nätverket och inte genom behandlingsinsatser. Han konstaterar också att beskrivningarna av de unga i utredningarna försvårar deras identitetsutveckling.

Sammanfattningsvis visar forskning på flera diskrepanser mellan avsikten med samhällsvård och hur den gestaltar sig för unga i samhällsvård.

Sofia Enell: Banor i samhällsvården - en tvåårsstudie om unga som utretts på SiS-institution 


\section{Tabell I.}

Unga i enkätmaterialet och intervjumaterialet. Antal, procent inom parentes.

\begin{tabular}{|l|l|l|l|}
\hline \multicolumn{2}{|c|}{} & $\begin{array}{l}\text { Enkätmaterial } \\
n=85\end{array}$ & $\begin{array}{l}\text { Intervjumaterial } \\
n=16\end{array}$ \\
\hline \multirow{2}{*}{ Kön } & Flicka & $33(39)$ & 6 \\
\cline { 2 - 4 } & Pojke & $52(61)$ & 10 \\
\hline \multirow{4}{*}{ Ålder } & Medelålder & 15,9 år & 15,3 år \\
\cline { 2 - 4 } & $12-14$ år & $37(43)$ & 8 \\
\cline { 2 - 4 } & $16-19$ år & $48(57)$ & 8 \\
\hline Lagrum för placering & Tvång & $74(87)$ & 10 \\
\cline { 2 - 4 } & Samtycke & $11(13)$ & 6 \\
\hline
\end{tabular}

\section{Metod}

Flera metoder och datakällor har använts i studien, vilket är lämpligt vid undersökningar av komplexa fenomen (Creswell, 2013). Datakällorna består av:

- Enkätsvar från yrkesverksamma avseende 85 utredningsplacerade unga på SiS-institutioner.

- Intervjuer med 16 unga och deras socialsekreterare.

- Utredningstexter från SiS-institutionerna för 15 unga.

\section{Undersökningsgrupp}

Under perioden 2010-09-01 till 2011-0228 placerades 151 unga för utredning vid 20 olika SiS-institutioner. Av de 151 unga kunde 110 nås och tillfrågas om deltagande. Slutligen kom 85 unga (56 procent av de 151 utredningsplacerade) fördelade på 18 institutioner att ingå i studien och följas genom enkäter. Förklaringar till bortfallet är flera, till exempel avsaknad av samtycke och att socialsekreterare inte besvarade enkäterna (Enell \& Denvall, 2013). Information om de unga som inte ingår i studien är begränsad, men de skiljer sig marginellt åt vad gäller könsoch åldersfördelning från dem som ingår. 16 av de 85 unga har även följts genom upprepade intervjuer. Urvalet bestod av samtliga placerade ungdomar vid två SiSinstitutioner och på tre utredningsavdelningar. Av 30 tillfrågade kom 16 att intervjuas vid flera tillfällen.

De unga som ingår i intervjumaterialet skiljer sig från de unga i enkätmaterialet $\mathrm{i}$ fråga om ålder och lagrum för placering. Att fler av de intervjuade hade samtyckt till sin placering förklaras av att de intervjuade kunde vara placerade på en av totalt två SiS-institutioner som tar emot samtyckesplacerade unga. De 85 unga skiljer sig från hela SiS ungdomsgrupp genom fler samtyckesplaceringar och lägre ålder (Enell \& Denvall, 2013).

\section{Genomförande}

Enkäter har besvarats av socialsekreterare vid två tillfällen: när de unga placerades för utredning och sex månader efter avslutad utredning. Utredningspersonal besvarade en enkät vid avslutad utredning. 
De 16 intervjuade ungdomarna kontaktades tre gånger: på utredningsavdelningen när utredningarna avslutades, ett år senare där de då befann sig och två år senare per telefon. Den första intervjun var semistrukturerad, medan den andra var öppen med fyra huvudfrågor: hur deras liv såg ut nu, vad som hänt efter utredningen, vilken betydelse de tillskrev utredningen samt hur de såg på framtiden. Vid det andra intervjutillfället fick de även ta del av tidigare intervjuutskrifter och möjlighet att kommentera tidigare utsagor. Den tredje kontakten var en uppföljningsintervju per telefon om deras situation. Med en av de unga gjordes denna avslutande intervju via e-post. Ett år efter utredningsplaceringarna intervjuades de 16 ungdomarnas socialsekreterare. Dessa intervjuer genomfördes per telefon med undantag för tre, då det fanns möjlighet att träffas istället. Frågorna som ställdes var vad som föranledde utredningsplaceringen, vad som hände efteråt samt vilken betydelse utredningen haft. Intervjuerna med de unga och socialsekreterare, som tog mellan 10-90 minuter, har spelats in och skrivits ut.

SiS-institutionernas utredningstexter har inhämtats för 15 av de unga (en samtyckte inte till att lämna ut utredningstexten). Uppgifter om åtgärdsrekommendationer har hämtats från dessa texter.

\section{Analys}

Data från enkätmaterialet har analyserats utifrån socialtjänstens följsamhet till förslagen i utredningarna samt omfattningen av instabilitet för de unga före och efter utredning.
Analysen av intervjumaterialet har följt följande steg:

- Individuella sammanställningar av intervjuutskrifterna med de unga och socialsekreterare samt åtgärdsrekommendationer i utredningstexterna, vilket resulterade i en kronologisk berättelse för varje ungdom.

- Genom en sammantagen analys av de ungas och socialsekreterarnas utsagor samt hur interaktionen dem emellan kom att framstå, har likheter och variationer framträtt och format banor.

- Uppgifter om planerade och oplanerade flyttningar, handläggarbyten och nya externa utredningsförfaranden, kopplades till de ungas banor. Med flyttningar avses placering i samhällsvård, ut ur samhällsvård samt mellan avdelningar eller vårdmiljöer inom samhällsvården. Med oplanerade flyttningar avses så kallade sammanbrott, dvs. avslut av placeringar utan att syftet med vården är uppnått. Sammanbrott kan initieras av den unge, förälder, vårdgivare eller socialtjänst (Egelund et.al., 2010:21; Sallnäs et.al., 2004). Med begreppet handläggarbyten menas att den socialsekreterare som ansvarar för den unges placering byts ut. Med externa utredningar avses utredningar av unga som utförs utanför socialtjänsten. Uppgifter om bedömningar från externa utredningar som skiljer sig från SiS-utredningen har noterats.

I analysen lades stor vikt vid de ungas utsagor och uppfattningar om utredningstiden, vad som hände därefter och deras interaktion med yrkesverksamma. Varje ung person har rimligtvis en unik

Sofia Enell: Banor i samhällsvården - en tvåårsstudie om unga som utretts på SiS-institution 
bana, men i analysen har vissa "typbanor" som demonstrerar likheter i interaktionen framträtt. Vissa inslag finns i flera ungas banor och gränsen dem emellan kan vara flytande. För två unga fanns det, mer än för övriga, inslag av flera banor varför deras banor redovisas separat.

\section{Etiska överväganden och begränsningar}

Samtycke har inhämtats från de unga och även från vårdnadshavare för dem under 15 år. De intervjuade lämnade vid den första intervjun samtycke till en ny intervju och vid den andra samtycke till intervju med socialsekreterare samt att utredningstexter kunde inhämtas. Studien har etikprövats och godkänts av Regionala etikprövningsnämnden i Linköping. Den har delfinansierats av Statens institutionsstyrelse.

Studiens begränsningar består i ett högt bortfall i enkätstudien (44 \%) samt ett litet urval i intervjumaterialet som skiljer sig något från gruppen unga i enkätmaterialet. Tillförlitligheten i uppgifter från de unga och socialsekreterare stärks av att de lämnats av båda. Samtidigt kan det finnas en underrapportering av flyttningar, handläggarbyten och externa utredningar när handläggare var nya och inte hade kännedom om den unge och när den unge inte kunde erinra sig hur det exakt gick till. Analysen är begränsad då den avser interaktionen mellan två aktörer. Även om dessa kan ses som centrala kan andra aktörer, till exempel ur de ungas informella nätverk, också ha deltagit i formandet av banorna.

\section{Fyra banor}

Nedan beskrivs fyra banor som har identifierats för de 16 intervjuade unga: kampbanan, dialogbanan, passagerarbanan och övertalningsbanan. Karaktäristika för varje bana presenteras och exemplifieras med hjälp av en fallbeskrivning. I figur och förklarande text illustreras sedan händelseförloppen för de unga utifrån flyttningar inom eller från samhällsvården $(\bullet)$, handläggarbyten $(\mathrm{X})$ och externa utredningar (//).

\section{Kampbanan}

Kampbanan utmärks av ungdomarnas och socialsekreterarnas skilda uppfattningar och fokus. De saknar tillit till varandra och samspelet kan liknas vid en kamp. Banan belyser tydligt två institutionella parallellvärldar (jmf Egelund et.al., 2010). Socialsekreterarna följer en logik där ett utmanande beteende leder till upptrappning av insatser med mer struktur och tvång. Socialsekreterarna uttryckte maktlöshet eller osäkerhet i försöken att styra de ungas liv. Genom utredningarna fick de handlingsalternativ och socialsekreterarna följde i hög utsträckning utredningarnas förslag. De unga å sin sida kände sig missförstådda, inte betrodda och saknade tron på att vuxna, särskilt socialtjänstens representanter, ville dem väl. Socialsekreterarnas upptrappning betraktades av de unga som straff och förstärkte deras negativa bild av socialtjänsten. De unga kunde tycka att de gjorde vad som efterfrågades, men när orken saknades och besvikelser infann sig kunde de vägra, göra motstånd eller avvika 
från placeringar. Att avsluta placeringarna eller göra dem mer öppna eftersträvades hela tiden av de unga, men förändringar avgjordes av yrkesverksamma. Utredningarna uppfattades meningslösa av de unga. Flera av de unga har även vad Egelund m.fl. (2010) beskriver som "nätverksfattigdom", dvs. en frånvaro av personer som man har en grundläggande tillit till och som man kan få stöd från i svåra situationer. Aziza 14 år, Jonas 16 år, Maria 16 år och Vincent 17 år ingår i kampbanan. ${ }^{4}$ Här exemplifierar Aziza kampbanan.

Aziza berättar att hon före utredningsplaceringen rymde och använde droger. Hon minns möten med socialtjänsten, men förstod inte innebörden: Jag trodde aldrig att de skulle göra någonting. Omställningen vid utredningsplaceringen blev stor och Aziza trivdes inte på utredningsavdelningen. När utredningspersonal och socialsekreterare beslutade att Aziza efter utredningen skulle vara fortsatt placerad på låst avdelning valde Aziza att hämnas: Jag ska hämnas på dom /.../ det enda som jag gjorde efter att jag vaknade var att gå omkring där, göra kalabalik. Kalabaliken bröts när Aziza utlovades en hemresa om hon skötte sig. Aziza följde regler och belönades med ökad frihet. Ett år efter utredningsplaceringen började Aziza känna sig färdig på SiS-institutionen: Jag ska inte vara här längre, jag har inte gjort något så varför ska jag vara här då. När det var dags för uppföljning och omprövning av tvångsvården fick hon beskedet: De säger till mig vi tror att du behöver stanna ett tag till (paus), dåalltså allting rasade igen (paus)

4 Alla namn i artikeln är fingerade för att ge de unga anonymitet. allt. Trots att hon själv uppfattade att hon skött sig, så var det inte nog: Det kändes som att dom krävde mer än vad jag kan ge. När Aziza åkte hem nästa gång valde hon att stanna kvar en vecka, vilket betraktades som en rymning. Rymningen tillsammans med institutionspersonalens bedömning om Azizas ytanpassning och manipulation gjorde att Azizas nya socialsekreterare valde fortsatt SiS-placering och tvångsvård.

En vändning skedde när socialsekreteraren ville träffa Aziza själv. De möttes på ett konditori i hemstaden och hon fick berätta för socialsekreteraren vad hon själv ville: Så berättar jag för henne att jag vill komma till fosterfamilj och jag orkar inte vara där och sedan så berättar jag allt för henne som jag känner. Socialsekreteraren konstaterade att hon har ju gjort vad hon ska, hon har ju rätt $i$ det och vann Azizas förtroende. Tillsammans med Aziza började hon planera flytt från SiSinstitutionen, där ett första steg blir flytt till öppen avdelning. Två år efter utredningen befann sig Aziza i ett familjehem där hon planerade att stanna.

Enligt Aziza hade varken personal eller socialsekreterare pratat med henne om utredningen efteråt, i vilket hennes socialsekreterare instämmer. Aziza hade inte läst utredningen: Så länge jag tycker vad jag tycker och dom tycker vad dom tycker, så är det klart att jag skiter i vad dom säger. Aziza förstår att livet hade kunnat se annorlunda ut om hon inte blivit omhändertagen: Jag försöker vara tacksam, men det ärjaginte.

I figuren nedan illustreras händelseförloppen för Aziza och de andra unga. Här framgår att de ungas första kontakt med 

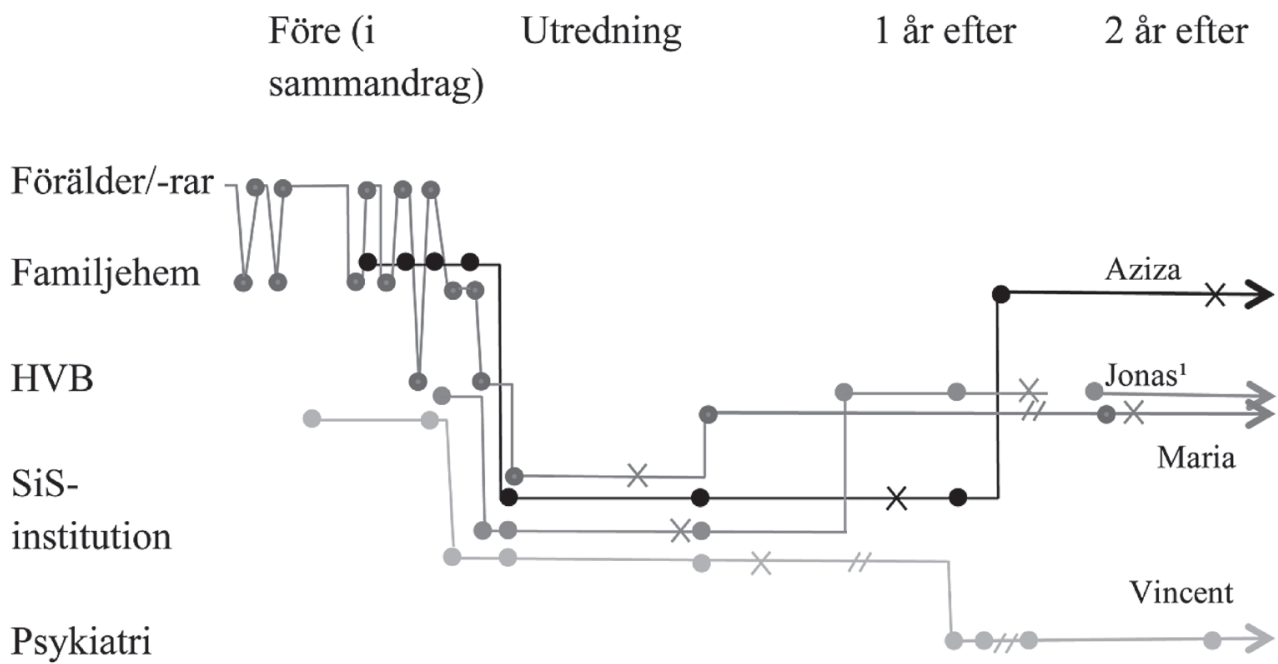

${ }^{1}$ Jonas är under en period bostadslös

\section{Figur 1. Händelseförloppen i kampbanan.}

socialtjänsten, förutom för Jonas, skedde före tio års ålder. Samtliga unga var placerade före utredningen och hade erfarenhet av flera oplanerade avbrott. De unga blev placerade med stöd av tvångslagstiftning och utredda på låsta avdelningar. Utredningsförslagen på placeringar följdes för alla utom för Maria och kortvarigt för Jonas. Efter utredningen var Azizas och Marias flyttningar planerade, medan flera av Vincents och Jonas var oplanerade. Alla har fått en eller flera nya socialsekreterare under studien. Vincent och Maria har utretts ytterligare, varav Vincents första utredning skedde på inrådan av SiS-institutionens utredning. Vincents diagnoser förändras vid de två efterföljande utredningarna.

De unga i kampbanan har en bakgrund som innebär en relativt långvarig kontakt med socialtjänsten samt tidigare erfarenheter av samhällsvård. Händelseförlop- pen efter utredningarna består av fortsatt instabilitet avseende flyttningar eller, som för Aziza, framflyttade flyttningar och förlängd tvångsvård samt socialsekreterarbyten. Azizas bana får efter konditorimötet med den nya socialsekreteraren en ny riktning. En riktning som kan uppfattas ha inslag av nästa bana, dialogbanan.

\section{Dialogbanan}

Till skillnad från de unga i kampbanan uppfattade de unga i dialogbanan att de yrkesverksamma kunde lyssna, visa respekt och låta dem få gehör för sina synpunkter. De unga menade att framförallt utredningspersonalen hade lyssnat och gett dem inflytande. Detta till trots uttryckte de unga, likt många andra placerade, att de saknade tillit till vuxna (Samuel \& Pryce, 2008). Även socialsekreterarna gav uttryck för bristande tillit till 
de unga men båda parter kunde visa förståelse och respekt för varandras agerande. Utredningstiden var jobbig men meningsfull för de unga. De uppfattade att de hade påverkat och accepterat åtgärdsförslagen och de interventioner som sedan skedde. Förändringar i banan kunde ske på initiativ av båda parter. De unga i dialogbanan hade ett stödjande nätverk, om än litet. Camilla 18 år, Paula 16 år, Alma 14 år och Julia 14 år är de ungdomar som ingår i dialogbanan och Paula utgör banans fallbeskrivning.

Paula berättade att det hade kunnat sluta illa för henne utan utredningsplaceringen: Jag ångrar inte att jag blev intagen för då hade jag inte suttit här idag. En akut situation föranledde placeringen och socialsekreteraren motiverade utredningen med: Nu behövde vi veta hur vi skulle fortsätta. Paula tyckte att utredningen hjälpte mig väldigt mycket med att få insikt, men var samtidigt arg på socialtjänsten: Jag var jättearg på socialtjänsten /.../ de hörde aldrig av sig. I utredningen lyckades Paula få utredningspersonalen att inte föreslå låst avdelning och hon sammanfattade: Vi har haft en bra dialog. Paulas socialsekreterare uppfattade utredningen som en bekräftelse på deras egna bedömningar och ageranden. Samtidigt gjordes en annan bedömning än utredningspersonalens angående Paulas samtycke till vård. Socialsekreteraren ansåg att Paula behövde fortsatt låst institution. Tillsammans med Paula sökte de plats och efter besök på annan SiS-institution placerades Paula för ny utredning och behandling. Paula var positiv till behandlingen, som var krävande, men där personalens stöd underlättade: Dom var väldigt tuffa, men dom var helt underbara.

Utan förvarning fick Paula flytta hem: Dom sa bara att nu flyttar du direkt. Socialsekreteraren förklarade: Paula plockades hem tidigare än vad som egentligen var sagt, men detta är ju också en kostnadsfråga från kommunen. Paula föll in i tidigare beteende, det blev sjukhusvistelse och HVB-placering. Paula flyttade sedan till ett familjehem där det efter ett halvår uppstod konflikter. Paula flyttade hem och skaffade sedan eget boende. Paulas berättelse kantas av vuxna som hon säger ha stöttat henne genom en jobbig tid: Alltså andra har ju hjälpt mig. Papper som hon samlat på sig hade slängts, däribland utredningen från SiS-institutionen, som hon inte mindes om hon hade läst.

När vi ser till händelseförloppen för de unga i dialogbanan var deras tidigare kontakt med socialtjänsten relativt kort. Alla utom Camilla fick sina första insatser mindre än ett år före utredningen (Alma, Julia och Paula). Camilla och Alma hade erfarenheter av tidigare placeringar och oplanerade avbrott. Samtliga var tvångsplacerade och utreddes på låsta avdelningar. Utredningarnas förslag på placering följdes inte för Alma och Paula. Paulas och Julias efterföljande placeringar avslutades i förtid och följdes av oplanerade flyttningar. Julia, Camilla och Paula fick nya socialsekreterare, varav Paulas var en följd av kommunens organisering. Camilla utreddes på nytt enligt SiS-institutionens rekommendationer, medan Paula utreddes igen som en del av behandlingen. 
Före (i

Eget boende

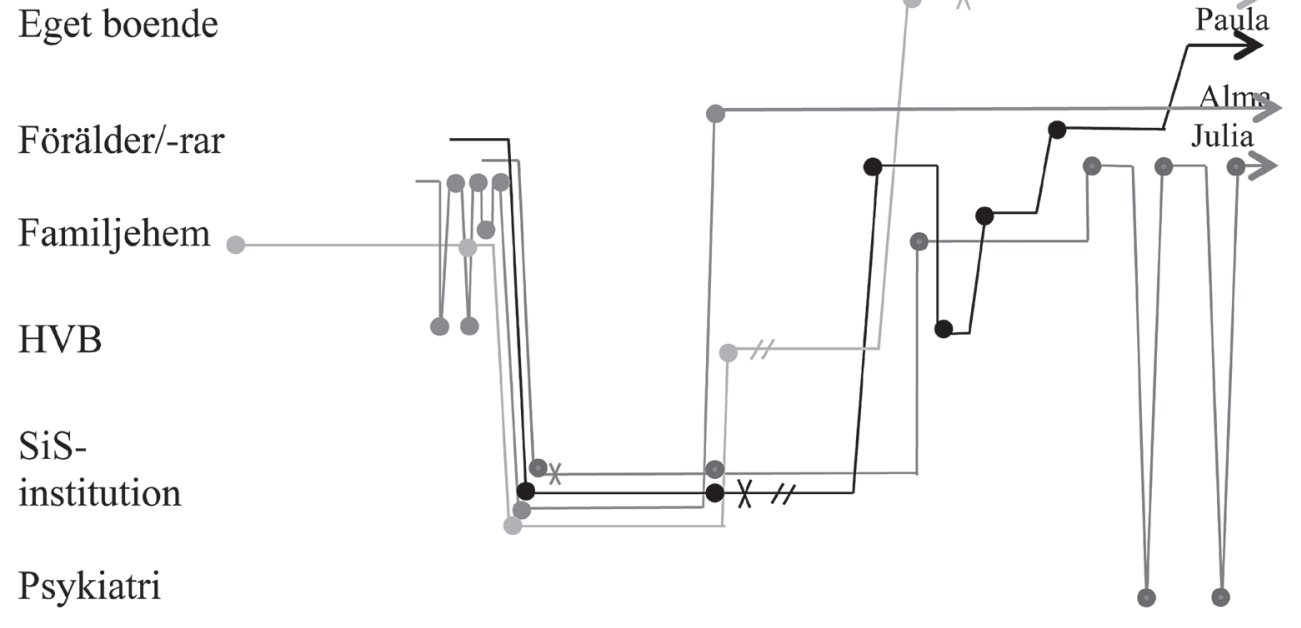

\section{Figur 2. Händelseförloppen i dialogbanan.}

Förutom kortare kontakter före utredningsplacering är skillnaderna få mellan händelseförloppen för dialogbanan och för kampbanan. Skillnaden ligger snarare i hur instabiliteten uppstått där instabilitet i dialogbanans händelseförlopp ofta skett efter att placeringar avslutats i förtid och, som för Paula, motiverats av resursskäl. Fyra flickor ingår i dialogbanan. I nästa bana, passagerarbanan, återfinns istället fyra pojkar.

\section{Passagerarbanan}

Passagerarbanan skiljer sig från de övriga banorna genom att både de unga och socialsekreterarna lät sig styras av andra. I formandet av banan intog de båda snarare en roll som passagerare än som förare. De unga i passagerarbanan hade en större tillit till vuxna än unga i övriga banor och accepterade i högre grad yrkesverksam- mas beskrivningar av sina problem och behov. Utredningsplaceringarna aktualiserades av invecklade livssituationer där socialsekreterarna bedömde att de själva saknade tillräcklig kompetens för att avgöra de ungas behov; de behövde experthjälp. De unga själva beskrev hur deras målsättning var att få komma hem igen och för att komma hem behövde de göra det andra ville - nämligen sköta sig. De unga hade inte fullt förtroende för socialtjänsten, men accepterade "läget". De tyckte att vuxna kunde lyssna, men att de sällan hörde vad de unga i själva verket sa (se även Skoog, 2013). Socialsekreterarna avvaktade i sin tur de ungas utveckling och gjorde nya bedömningar utifrån hur behandling eller planering fortskred. De unga var ofta mindre delaktiga i denna process. Socialsekreterarna uppfattades vara beroende av andras bedömningar och familjens inställning, vilket ger ett intryck 
av lösryckta, ad-hoc-bedömningar. Socialsekreterarna menade att de ungas föräldrar hade brister i sina föräldraförmågor. De unga i passagerarbanan är Max 12 år, Anton 14 år, Gustav 14 år och Rafaat 16 år. Gustav är banans exempel.

Gustav hade erfarenhet av flera oplanerade avbrott och såg de tidigare flyttningarna som anledning till utredningsplaceringen: Man kan ju inte bara flytta på en hela tiden utan då tänkte de att vi gör väl en utredning då. För socialsekreteraren var utredningen ett sätt att ge rätt behandling: Utredas ordentligt så vi vet att när vi då placerar honom igen så fär han rätt behandling och vård. Gustav trivdes på SiS-institutionen och fann delar av utredningen meningsfull: Det har ju varit skönt och så att prata. Gustav hoppades att det skulle bli bättre efter utredningen: Men nu tänker jag så att om jag bara skärper mig så behöver jag inte flytta runt. I utredningen föreslogs HVB-placering med specialistkunskaper om Gustavs problematik. Gustav höll inte med, men sa: Jag tänker att dom kanske vet bättre än mig. Gustav placerades på ett HVB och han konstaterade ett år senare: Det är väl det bästa som hänt i mitt liv hittills att jag kom hit.

När personalen på Gustavs HVB tyckte att det var dags för Gustav att flytta blev socialsekreteraren villrådig. HVB-personalen ansåg att Gustav borde flytta till familjehem eller tillbaka hem, men socialsekreteraren såg att Gustav, av olika skäl, inte kunde flytta hem. Gustav hade svårt att förstå varför han inte kunde flytta hem: När jag är klar här på (HVB) dåär jag klar med allting /.../ då är jag ju klar med min behandling. Gustav berättade att beskedet om var han skulle bo dröjde: Det var jobbigt för jag visste ingenting. Först blev han mot sin vilja placerad på ett ungdomsboende för att kort därefter flytta till ett annat och vid tiden för vår tredje intervju skulle han snart flytta igen. När han tänker tillbaka på utredningen säger han att: det känns som att det var en vändning och förklarar att: man liksom måste skärpa sig om man vill någonstans i livet.

Den första kontakten med socialtjänsten för de unga i passagerarbanan varierar från småbarnsåren (Max) till runt tio-tolvårsåldern (Gustav, Anton) och 15-årsåldern (Rafaat). För Max och Rafaat var utredningsplaceringen på SiS-institution, som alla utom Rafaat samtyckt till, deras första placering. Förslagen från SiS-utredningarna på placering, särskilda behandlingar och nya utredningar följdes av socialtjänsten. De ungas flyttningar var, förutom Max omplacering till familjehem, planerade. Alla utom Gustav har fått nya socialsekreterare efter utredningen, där Rafaats socialsekreterarbyte berodde på kommunens organisering. I enlighet med SiS-utredningens rekommendationer genomgick samtliga nya utredningar. I dessa utredningar skedde nya bedömningar för Rafaat och Max som gick emot bedömningarna från SiS-institutionen. Två år efter utredning hade alla unga insatser från socialtjänsten, varav tre av fyra var kvar i samhällsvård.

Till skillnad från kamp- och dialogbanan framstår passagerarbanan som mer stabil avseende flyttningar. Däremot sker flera handläggarbyten och ytterligare utredningar. För Gustav och de andra unga i passagerarbanan ser tiden i samhällsvård

Sofia Enell: Banor i samhällsvården - en tvåårsstudie om unga som utretts på SiS-institution 

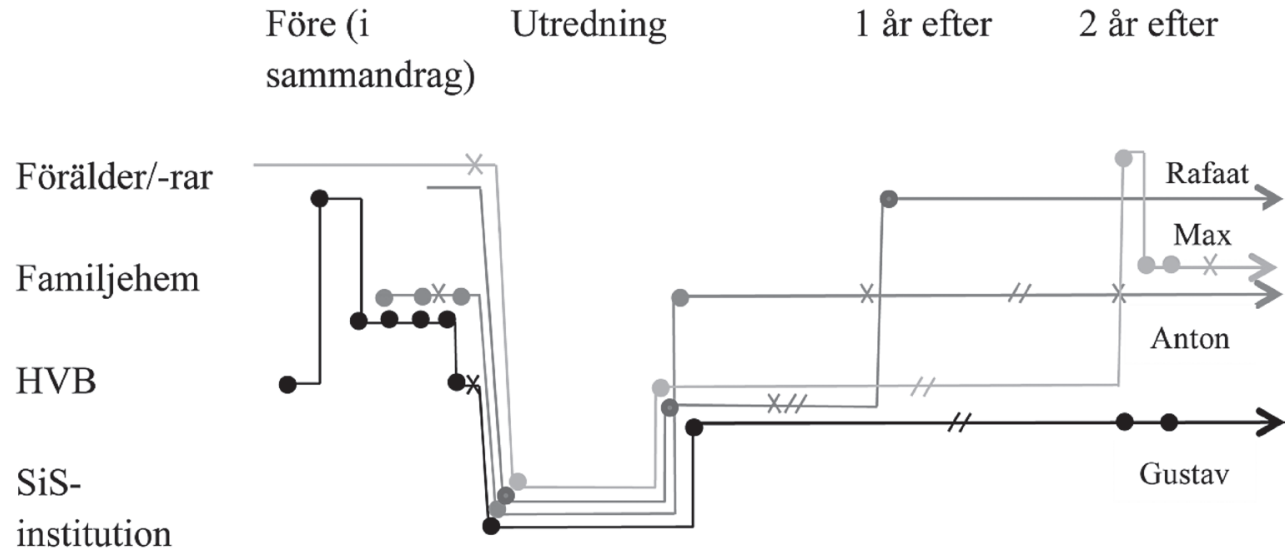

\section{Figur 3. Händelseförloppen i passagerarbanan.}

ut att bli långvarig. För de unga i nästa bana, den sista, kom den istället att bli kortvarig.

\section{Övertalningsbanan}

De unga i övertalningsbanan hade en kluven relation till socialtjänsten. De var inte direkt hjälpsökande, men av olika anledningar, beroende av stöd från socialtjänsten. De unga efterfrågade sådant som familjehem och skuldsanering, men övertalades under hot om tvång till utredningsplacering. Socialsekreterarna ville utreda då tidigare åtgärder inte varit tillräckliga. De unga, som samtyckt till placeringarna, ansåg inte att utredningarna bidrog med något och liksom de unga i kampbanan hade de svårt att förstå syftet med utredningarna. Tillvaron på SiS-institutionen blev en väntan på att komma därifrån. Tiden efter utredningen utmärktes av besvikelser, då åtgärderna inte mötte de ungas förväntningar. Socialsekreterarna kämpade själva med bristande resurser och att motivera de unga till insatser. Socialsekreterarna försökte följa utredningsrekommendationerna. Mindre än ett år efter utredningen hade de unga lämnat samhällsvården och de positiva förändringar som skett uppfattade de berodde på dem själva. De gav uttryck för uppgivenhet och att socialtjänsten svikit dem. Liksom de unga i Samuel och Pryces (2008) studie framstår de som "överlevare", där deras självtillit utgör både ett skydd och en risk för kommande relationer. De ungas familjerelationer var sköra och de fick ta eget ansvar för sin situation. Niklas 17 år och Hassan 17 år ingår i övertalningsbanan. Niklas har fått exemplifiera banan.

Niklas problem före utredning beskrevs av både Niklas och hans socialsekreterare vara psykisk ohälsa och drogmissbruk. Niklas ville till ett familjehem. Att det först blev en utredning förklarade Niklas med att han hade att välja på det eller tvångsvård: Det blir ett LVU till behandlingshem eller sånt och då tog jag detta. Han försökte avbryta placeringen, men övertalades att stanna kvar av sin socialsekre- 


\section{Före (i Utredning 1 år efter 2 år efter sammandrag)}

Förälder/-rar

Familjehem

HVB

SiSinstitution

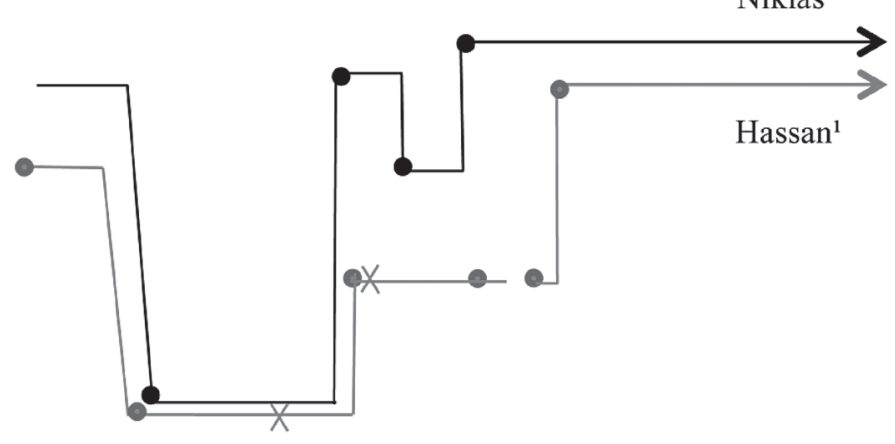

${ }^{1}$ Hassan är under en period bostadslös

\section{Figur 4. Händelseförloppen i övertalningsbanan.}

terare: Vi kunde motivera honom att vara kvar för att han skulle få den hjälpen han behövde. I utredningen föreslogs att Niklas skulle placeras i ett familjehem, få kontaktperson och samtalsstöd för sitt missbruk samt samtal med sin mamma.

Efter utredningen flyttade Niklas hem där han återupptog sitt missbruk. Efter fem veckor fann socialsekreteraren till slut ett familjehem. Niklas samtyckte och sa: Jag ville ju komma ifrån här då också ju, mycket var skit. Niklas berättade att flytten till familjehemmet känns konstig och att han kunde fortsätta missbruka där. Niklas fick inga samtal för sitt missbruk eller med sin mamma, men en kontaktperson. Det blev flera uppslitande bråk i familjehemmet och första hemresan skedde efter tre månader när drogproverna, trots fortsatt missbruk, visat negativt. Niklas bestämde sig sedan för att lämna familjehemmet. Väl hemma återstod två möten på socialtjänsten, där socialsekreteraren resultatlöst försökte övertala Niklas att återvända. Om SiSutredningen säger hans socialsekreterare att hen hade lyssnat på deras bedömning och: att den bedömningen stämde sedan. Men sedan så hände ju saker och så ändrade sig ju Niklas. Niklas saknade inte kontakten med socialtjänsten: Det som var riktigt skönt nu var att slippa alla möten på soc. /.../ Så trodde dom säkert att jag inte skulle klara det.

Efter en sommar med fortsatt missbruk började Niklas skolan. Han fick nya lärare som han sa var unga som förstår. Niklas satte upp nya mål och bestämde sig för att sluta missbruka: Jag fick ångest för jag tänkte på mitt liv. Niklas ägnade en del tid åt att spela om pengar och sa om sig själv: Jag har ju väldigt lätt för att bli beroende. Två år efter utredningen berättade Niklas att han gick på gymnasiet, hade slutat med droger och hade kontroll över sitt spelande. När Niklas tänkte på utredningen sa han: Inte något som hjälper mig idag och att han inte hade läst den. 


\section{Före (i Utredning $\quad 1$ år efter 2 år efter sammandrag)}

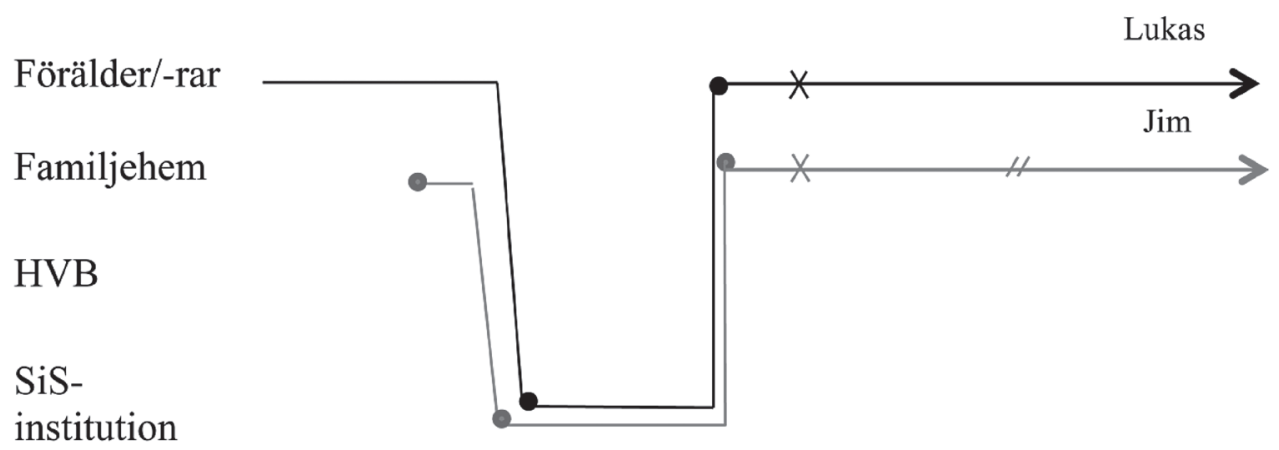

\section{Figur 5. Händelseförloppen för Jim och Lukas.}

Händelseförloppet för de unga i övertalningsbanan blir efter utredningen, till skillnad från övriga banor, kortvarigt. De unga har haft kontakt med socialtjänsten $i$ ett till två år före utredningsplaceringen. Hassans tidigare familjehemsplacering avbröts oplanerat innan han utredningsplacerades. Både Niklas och Hassan avbröt de efterföljande placeringarna av missnöje. Ingen av dem utreddes ytterligare, men Hassan har fått nya socialsekreterare varav ett byte föranleddes av kommunens organisering.

Förutsägbarhet och stabilitet avseende flyttningar saknas helt för de unga i övertalningsbanan. $\mathrm{Nu}$ återstår presentation av två unga.

\section{Jim och Lukas}

Både Jim och Lukas var 14 år när de utredningsplacerades. Deras banor har inslag av flera av de ovan beskrivna. För Jim finns det inslag av passagerarbanan, då placeringen efter utredningen var stabil, han fick ny handläggare och utreddes på nytt.
Men Jim var vid samtliga tre intervjutillfällen negativ till utredningsplaceringen. Efter utredningen var han nöjd och planerade att stanna i sitt familjehem till dess att han kunde flytta till något eget. Lukas bana stämmer med övertalningsbanan. Med hot om tvång placerades Lukas för utredning och ett år efter utredningen hade han avslutat alla kontakter med socialtjänsten. Men två år efter utredningen var kontakten återupptagen genom stödsamtal och kontaktperson. Liksom Jim var Lukas kritisk till utredningsplaceringen.

Lukas har haft kontakt med socialtjänsten sedan fyraårsåldern, men utredningsplaceringen var hans enda erfarenhet av samhällsvård. Förslaget från SiS-utredningen följdes inte av socialtjänsten då varken Lukas eller föräldrarna samtyckte. Att Lukas fick ny socialsekreterare förklarades av organisatoriska skäl. Jims familjehemsplacering före utredningen avbröts oplanerat, men familjehemsplaceringen efter utredningen ser ut att bli varaktig. 


\section{Händelseförlopp för hela gruppen unga}

Här följer händelseförloppen för hela gruppen unga i studien, detta för en mer övergripande kunskap om vad som hände efter SiS-utredningarna.

Av enkätsvaren framgår att en majoritet av de 85 unga (59\%) var placerade i samhällsvård när de utredningsplacerades. Sammanlagt hade 64 procent erfarenhet av tidigare placeringar. I SiS-utredningarna rekommenderades de flesta (84 \%) fortsatt placering. Nio av tio socialsekreterare tillskrev utredningarna och förslagen på åtgärder stor betydelse för socialtjänstens fortsatta bedömningar och beslut, något som avspeglas i följsamheten till förslagen på åtgärder i utredningarna. 79 procent av de unga hade sex månader efter utredningen någon gång befunnit sig i den boendeform (SiS-institution, HVB, familjehem eller föräldrahemmet) som föreslogs i utredningarna.

Placeringarna blev för många kortvariga, särskilt vid HVB. Sex månader efter utredning hade 24 procent av de unga omplacerats och för 20 procent hade sammanbrott skett. Andelen unga med erfarenhet av sammanbrott ökade från 39 procent före utredning till 44 procent sex månader efter. Samtliga sammanbrott utom ett skedde i den placering som föreslogs i utredningen. Utredningarna tycks alltså inte ha motverkat sammanbrott.

Även instabilitet gällande de ungas socialsekreterare framträder. Mer än var tredje ung person (39\%) hade, från att de placerades för utredning till sex månader senare, haft flera socialsekreterare. De flesta av socialsekreterarna (23 av 33) byttes ut då den tidigare slutat på sin tjänst och för de övriga berodde det på organisatoriska förhållanden i kommunerna, t.ex. att unga får olika handläggare beroende på om de utreds eller får interventioner.

En tredjedel av de unga (28\%) rekommenderades fortsatt utredning eller uppföljning, varav tre av fyra hade genomförts ett halvår efter utredningen eller skulle komma att genomföras. Av enkätsvaren framgår emellertid att SiS utredningsbedömningar kunde ifrågasättas i efterhand av socialsekreterare.

\section{Sammanfattning och slutsatser}

Syftet var att analysera en sekvens av ungas banor i samhällsvården i relation till SiSutredningar. Analysen har varit fokuserad på de banor som formats genom interaktionen mellan unga och socialsekreterare samt händelseförloppen i dessa banor och i hela gruppen av unga utifrån stabilitet och instabilitet. Fyra typer av banor i samhällsvården, med olika karaktäristika, har blivit synliga: kampbanan, dialogbanan, passagerarbanan och övertalningsbanan. Kampbanan formades av motsatta positioner mellan unga och socialsekreterare och uppvisade instabila händelseförlopp och tvångsvård. Dialogbanan formades av viss ömsesidig kommunikation, men innebar också viss instabilitet och oförutsägbarhet i händelseförloppen. Passagerarbanan formades i ett beroende av andra aktörer, vilket ledde till händelseförlopp med viss stabilitet men också osäkerhet för de unga. Avslutningsvis formades övertalningsba-

Sofia Enell: Banor i samhällsvården - en tvåårsstudie om unga som utretts på SiS-institution 
nan i rummet mellan frivillighet och tvång samt av båda parters besvikelser på utebliven stabilitet. Oavsett bana uppfattades sällan händelseförloppen som begripliga; de unga gav snarare uttryck för osäkerhet och oförståelse för förloppen. Trots omfattande utredningar och att utredningsförslagen följts för de flesta, utmärks händelseförloppen av instabilitet. För hela gruppen av unga i enkätmaterialet var andelen sammanbrott efter SiS-utredningen 44 procent. Detta är ett resultat som i relation till andra studier påvisar en hög andel sammanbrott (Egelund et.al., 2010; Sallnäs et.al., 2004). I intervjumaterialet hade de 16 unga haft 48 flyttningar (64 inklusive utredningsplaceringen) under den analyserade sekvensen, varav 13 var oplanerade. Tiden efter utredningen har därmed adderat flera nya sociala arenor till de ungas liv. Likaså har instabilitet genom handläggarbyten och nya bedömningar av de ungas behov framkommit, såväl för de 16 unga som för hela gruppen av unga.

En övergripande slutsats är att SiSutredningar inte utgör någon tydlig markör för ökad förutsägbarhet för de ungas banor. I vissa fall är utredningarna snarare isolerade företeelser, medan de $i$ andra fall har bidragit till att ge banan en viss riktning. De unga och socialsekreterarna har olika uppfattningar om händelser i banorna och det visar vilken betydelse perspektivvalet får. Trots att alla unga i gruppen genomgår SiS-utredning och att olika former av instabilitet framträder på gruppnivå, gestaltar sig de ungas tid i samhällsvård på olika sätt i unika och komplexa sociala processer.

\section{Diskussion}

\section{Skilda uppfattningar}

Socialsekreterarnas och de ungas utsagor om utredningarnas betydelse skiljer sig åt. Socialsekreterarna hade hög tilltro till utredningarna, vilket också fick betydelse för deras beslut. För de unga varierade deras uppfattningar om utredningarna. I två banor, dialogbanan och passagerarbanan, uppfattade de unga att utredningen gav dem ökad insikt eller var viktig för placeringen som följde. Dessa unga uppfattade sig delaktiga i eller accepterade utredningsförfarandet och interventionerna. De unga i de två andra banorna, kampbanan och övertalningsbanan, uppfattade inte att utredningen tillförde något, vilket i kampbanan hörde ihop med att de unga inte accepterade den fortsatta planeringen. Övertalningsbanan handlade snarare om att de unga var beroende och övertalades till placeringar de själva inte uppfattade innebar någon faktisk förändring.

Ett sätt att förstå de skilda uppfattningarna är att de unga och de yrkesverksamma befinner sig i institutionella parallellvärldar (Egelund et.al., 2010). De unga är orienterade mot vad de anser är normalt: att bo hemma, vara med vänner och inte ha kontakt med socialtjänsten. De yrkesverksamma är istället inriktade på en mer djupgående förändring av de ungas personlighet. Svårigheterna att förmedla till de unga vad som ska uppnås med placeringarna kan ses som en följd av skilda målsättningar. De ungas låga förväntningar och tillit till socialtjänsten, som bekräftas 
i tidigare studier (Egelund et.al., 2010; Samuel \& Pryce, 2008), kan också tänkas ha betydelse för hur de unga uppfattar interventionerna och påverka möjligheterna att skapa förutsägbarhet $\mathrm{i}$ banorna.

\section{Sociala processer}

Förloppet och åtgärderna efter utredningarna styrs av synnerligen komplexa, sociala processer. Det framgår att de ungas inställning och möjlighet att påverka skiljer sig åt mellan banorna. Detta hänger samman med hur de yrkesverksamma tolkar de ungas beteende. De ungas eget inflytande i dialogbanan skiljer sig från de ungas inflytande i övertalningsbanan. De senare fick inflytande då deras problematik inte uppfattats motivera tvångsvård. De unga i kampbanan var däremot tvångsvårdade, men upplevde framförallt att de ständigt blev missförstådda. Deras försök att påverka resulterade istället $i$ att försöken omskrevs till problembeteenden, som motiverade fortsatta eller ökade restriktioner i vården. Liksom Espersen (2010) visar ger yrkesverksammas problembeskrivningar ramar för dem att agera utifrån och om problembeskrivningarna ändras möjliggörs nya handlingsalternativ. För de unga i passagerarbanan har invecklade problemsituationer gjort dem utelämnade till socialtjänsten och yrkesverksammas problembeskrivningar. Resultatet blev för dem ett begränsat handlingsutrymme. De unga i dialogbanan, som enbart var flickor med ett litet stödjande nätverk, är de enda som själva uppfattade att de fått inflytande. Dialogbanans unga framstår som vältaliga och reflekterande.
Kanske ges ett större inflytande till unga med förmågan att kommunicera verbalt och på ett sätt som accepteras av yrkesverksamma?

De riktningar som banorna tog efter utredningarna har visat sig kunna ändras. För de unga har dessa kursändringar (för vändpunkter se: Berglund, 1998) uppstått i relationer, men även genom ökad självinsikt. Strauss m.fl. (1997) skriver att när det finns olika valmöjligheter kan beslut vid kritiska punkter få djupgående konsekvenser. Studien har belyst några sådana kritiska punkter i de ungas banor. Att förlänga Azizas vård och ta hem Paula tidigare än planerat är exempel med problematisk utgång. Konditorimötet med Aziza illustrerar däremot tillit och förtroende. Kursändringar kan framstå som plötsliga och ett resultat av särskilda aktörers ingripanden. Men vid närmare analys är de också ett resultat av längre processer och blir därför en fråga om tajming. Öppningar för att få tillit från unga i samhällsvård är få och kräver därför närvaro och tillgänglighet för att vara där när tillfället ges. Niklas insikt om sin beroendeproblematik är också ett exempel på en längre process som kan vara ett uttryck för mognad och nytt stöd från omgivningen, $\mathrm{i}$ detta fall skolan.

\section{Systemkonstruerad och ny form avinstabilitet}

Viss instabilitet kan ses som konstruerad av systemet i sig, något som belystes av händelseförloppen i de ungas banor. De unga flyttades framförallt planerat som ett led i en upptrappning till mer struktu- 
rerade former eller som nedtrappning till mer öppna former (se även Ward, 2009). Liksom dessa planerade flyttningar bidrar även utredningsplaceringen med nya arenor för de unga. Egelund m.fl., (2010) fann även att instabilitet kunde förklaras av organisatoriska resurser. Detta finns belyst i materialet där Paulas i förtid avslutade placering motiverades av ekonomiska skäl.

En annan form av "systemkonstruerad instabilitet" är omsättningen av socialsekreterare som berörde 39 procent av de unga i enkätmaterialet och 13 av 16 unga i intervjumaterialet. Sammanlagt hade de intervjuade haft 33 socialsekreterare varav fyra byten berodde på kommunens organisering. Socialsekreterare har en central roll på det sättet att de deltar i för de unga avgörande beslut, men de är samtidigt avlägsna eftersom de inte är involverade i de ungas vardag. Diskontinuiteten vad gäller socialsekreterare riskerar därför att ytterligare öka avståndet till de unga. Detta får också konsekvenser för vilken betydelse SiS-utredningarna kan få samt för möjligheten att skapa meningsfulla relationer och tajma kursändringar.

En form av instabilitet som inte framkommit i tidigare studier är i nya bedömningar av de ungas behov. 10 av 16 unga hade förnyade utredningar, varav fyra förändrade bedömningarna från SiSutredningarna. När nya utredningar kommer fram till nya slutsatser och diagnoser kan de ungas tillvaro förändras på nytt. Utredningsarbete är förknippat med stora utmaningar; (Munro, 1996) att utreda ungas svårigheter och att avgöra vilka åtgärder som ska vidtas framstår som ett komplicerat uppdrag. För vissa unga formas banan under synnerligen problematiska omständigheter, där nya utredningar och bedömningar blir återkommande inslag.

\section{Avslutning}

Både unga och yrkesverksamma eftersträvar, utifrån sina perspektiv, förutsägbarhet och kontroll. Men, liksom Strauss m.fl. (1997) påpekar, har ingen part full kontroll över banan. De unga i denna studie befann sig dels i problematiska livssituationer och i vissa fall tvångsvård, dels $\mathrm{i}$ en intensiv utvecklingsfas och frigörelseperiod. Med dessa förutsättningar är det för yrkesverksamma en stor utmaning att forma förutsägbara och stabila banor tillsammans med de unga. Analysen visar på vikten av att varje ung persons utsagor och erfarenheter beaktas i den fortsatta planeringen, och att planeringen av åtgärder görs begriplig för de unga. Den systemkonstruerade instabiliteten av flyttningar och socialsekreterarbyten samt återkommande bedömningar riskerar äventyra möjligheterna för detta. 


\section{Referenser}

Andersson, G. (2008). Barndomens placeringar och ungas tillbakablick. Socialvetenskaplig tidskrift, 15 (2), 76-96.

Bengtsson, T. T. (2012). Boredom and action - Experiences from youth confinement. Journal of Contemporary Ethnography, 41(5), 526-553.

Berglund, S.-A. (1998). Val av livsstil. Problemungdomars sätt att hantera verklighet och konstruera identitet. Umeå: Institutionen för socialt arbete, Umeå universitet.

Christiansen, Ø., Havik, T. \& Anderssen, N. (2010). Arranging stability for children in long-term out-of-home care. Children and Youth Services Review, 32(7), 913-321.

Creswell, J. W. (2013). Qualitative inquiry \& research design. Choosing among five approaches. (3rd ed.). Los Angeles: SAGE Publications Inc.

Egelund, T. \& Frydensbjerg, G. (2011). ”At give drengene en god tid." Pædagogisk praksis på sikrede institutioner for unge. In T. Egelund \& T. Jakobsen Böcker (Red.), Døgninstitutionen. Motscetninger og strategier når børn och unge anbringes. København: Hans Reitzels forlag.

Egelund, T. \& Jakobsen, T. B. (2011) Inledning. I T. Egelund \& T. B. Jakobsen (Eds.), Døgninstitutionen. Motscetninger og strategier når børn og unge anbringes, København: Hans Rietzels Forlag.

Egelund, T., Jakobsen, T. B., Hammen, I., Olsson, M. \& Høst, A. (2010). Sammenbrud $i$ anbringelser af unge. Erfaringer, forklaringer og årsagerna bag. København: Det Nationale Forskningscenter for Velfærd.

Enell, S. \& Denvall, V. (2013). Vägen från utredning till åtgärd. Utredningsplaceringar vid särskilda ungdomshem. Institutionsvård i fokus, $\mathrm{nr}$ 3: Statens institutionsstyrelse.

Espersen, L. D. (2010). Bekymrende identiteter. Anbragte børns hverdagsliv på behandlings- hjem. København: Sociologisk institut, Københavns Universitetet og Det Nationale Forskningscenter for Velfærd.

Fisher, M., Marsh, P., Phillips, D. \& Sainsbury, E. (1986). In and Out of Care. The experiences of Children, Parents and Social Workers. London: B.T. Batsford Ltd.

Glaser, B. \& Strauss, A. L. (1968). Time for Dying. Chicago:Aldine.

Levin, C. (1998). Uppfostringsanstalten: om tvång $i$ föräldrars ställe. Lund:Arkiv.

Lundström, T. \& Sallnäs, M. (2012). Tvång och marknad. De särskilda ungdomshemmen och deras omgivningsvillkor. In L. Ryberg-Welander (Red.), Rätt, social utsatthet och samhälleligt ansvar: festskrift till Anna Hollander. Stockholm: Norstedts Juridik.

Michanek, A., Kristiansson, M., Westermark, R.-M. \& Machado, B. (2000). Tiden på Älvan och ett år efter... 25 pojkars syn på vistelsen samt uppföljning ett år efter utskrivning. SiS följer upp och utvecklar, nr 5: Statens institutionsstyrelse.

Munro, E. (1996). Avoidable and Unavoidable Mistakes in Child Protection Work. British Journal of Social Work, 26(6), 793-808.

Oosterman, M., Schuengel, C., Wim Slot, N., Bullens, R. \& Doreleijers, T. (2006). Disruptions in foster care: A review and meta-analysis. Children and Youth Services Review, 29(1), 53-76.

Pösö, T. \& Eronen, T. (2013). Five years in care: documented lives and time trajectories in child welfare. Child \& Family Social Work, april 2013.

Sallnäs, M., Vinnerljung, B. \& Kyhle-Westermark, P. (2004). Breakdown of teenage placements in Swedish foster and residential care. Child \& Family Social Work, 9(2), 141-152.

Samuel, G. M. \& Pryce, J. M. (2008). "What doesn't kill you makes you stronger". Survivalist self-reliance as resiliance and risk among young adults aging out of foster care. Children

Sofia Enell: Banor i samhällsvården - en tvåårsstudie om unga som utretts på SiS-institution 
and Youth Services Review, 30 (10), 1198-1210. Sandell, G. \& Olsson, J. (1998). Bli sedd, välja väg och förändras. Utvärdering av utredningsarbetet vid Villa Ljungbacken, en ungdomsinstitution inom SiS. SiS följer upp och utvecklar, nr 2: Statens institutionsstyrelse.

Sarnecki, J. (1992). 12-månadersuppföljning. Uppföljning av \$12-vården i Stockholms län. Delrapport 4: Stockholms läns landsting, Omsorgsnämnden.

Shannon, D. (2011). Follow-up of youths admitted to SiS youth care facilities 1997-2001. Institutionsvård i fokus, nr 4: Statens institutionsstyrelse.

Skoog, V. (2013). Barns upplevelser av instabil samhällsvård. Socialvetenskaplig tidskrift, 20(1), 35-52.

Skoog, V., Dalin, R., Rönnbäck, E. \& Khoo, E. (2012). Instabilitet för barn i samhällsvård. Socionomens forskningssupplement, 31, 34-43.

Socialstyrelsen. (2013). Barn och unga - insatser år 2012. Vissa insatser enligt socialtjänstlagen (SoL) och lagen med särskilda bestämmelser om vård av unga (LVU).

Soeffner, H.-G. (1991). "Trajectory" as intendend fragment: the critique of empirical reason according to Anslem Strauss. In D. R. Maines (Ed.), Social organization and social process. New York: Walter de Gruyter Inc.
Spånberger Weitz, Y. (2011). Ungas erfarenheter av skola, samhällsvaird och vuxenblivande: Avhandling. Institutionen för socialt arbete, Stockholms universitet.

Stein, M. (1994). Leaving Care, Education and Career Trajectories. Oxford Review of Education, 20(3), 349-360.

Stokholm, A. (2006). Anbragte børn mellem kammerater og poedagoger. En antropologisk analyse af socialitet og identitetsdannelse på døgninstitution. Aarhus: Institut for antropologi, arkæologi og lingvistik, Aarhus Universitet.

Strauss, A. L., Fagerhaugh, S., Suczek, B., \& Weiner, C. (1997). Social organization of medical work. New Jersey:Transaction Publishers.

Sundell, K., Egelund, T., Andrée Löfholm, C., \& Kaunitz, C. (2007). Barnavairdsutredningar en kunskapsöversikt (2., rev. uppl. ed.). Stockholm: Gothia/Institutet för utveckling av metoder i socialt arbete.

Ward, H. (2009). Patterns of instability: Moves within the care system, their reasons, contexts and consequences. Children and Youth Services Review, 31, 1113-1118.

Vogel, M. A. (2012). Särskilda ungdomshem och vårdkedjor: Om ungdomar, kön, klass och etnicitet. Stockholm: Institutionen för socialt arbete, Stockholms universitet. 


\section{Summary}

\section{Young people assessed in secure units Trajectories in out-of-home care}

At the request of social service authorities, young people are assessed by a multi-professional team at secure accommodations. The assessments lead to care recommendations for the social service to decide about, recommendations expected to provide a more foreseeable and stable time in care. Research has shown that youth in out-of-home care might encounter more complexity instead of the desired stability and security. The aim of this research was to analyse a sequence of assessed young people's trajectories in outof-home care in relation to the assessments. The sequence constitutes the period from the assessments and two years ahead. Strauss's analytical concept of "trajectory" has been used to analyse the characteristics of the social processes in which the young persons were involved. The young people's trajectories were analysed by the interaction of young people and social workers, the central actors. The courses of events regarding stability and instability were connected to the analysis. Multiple methods have been used: interviews with 16 youths and 16 social workers as well as surveys among social workers concerning 85 young people.

The analysis displayed four different trajectories: the battle, the dialogue, the passenger and the persuasion trajectory, all with greater or lesser instability in different forms. The young people rarely perceived the courses of events as comprehensible and the assessment did not constitute a definite marker of increased stability and foreseeability. In conclusion, despite instability at group level, the young people's time in care was portrayed in unique and complex social processes. The result emphasize the importance for all professionals of paying attention to each young person's experiences. 